\title{
Major Autohemotherapy as a treatment modality for alveolar osteitis
}

\author{
Mosaad Abdaljawwad Khalifah \\ Faculty of Dentistry, KafrelSheikh University, Egypt
}

\section{ABSTRACT}

\section{OPEN ACCESS}

\section{Citation}

Khalifah, MA. Major Autohemotherapy as a treatment modality for alveolar osteitis. J Ozone Ther. 2018:2(3) doi: 10.7203/jo3t.2.3.2018.11292

\section{Academic Editor \\ Jose Baeza-Noci, \\ School of Medicine, Valencia \\ University, SPAIN}

\section{Editor}

World Federation of Ozone Therapy, Bologna, ITALY

\section{Received}

December 24, 2017

\section{Accepted}

February 6, 2018

Published

December 15, 2018

\section{Intellectual Property}

Khalifah, MA.

This is an open access article distributed under the terms of the Creative Commons Attribution License (CC BY 4.0), which permits unrestricted use, distribution, and reproduction in any medium, provided the original author and source are credited.

\section{Author Information}

mosaad_khalifa@den.kfs.edu.eg
Purpose. Alveolar osteitis is the most common post-odontectomy complication. Although blood clot disintegration is known to be the cause of the condition, an agreement is lacking regarding a treatment of choice. The aim of the current study therefore was to evaluate major autohemotherapy as one treatment method.

Patients and Methods. A total of 183 patients were categorized into 4 groups (I, II, III, and IV) according to pain severity (mild, moderate, severe, or agonizing, respectively). Major autohemotherapy was performed for all patients by withdrawing $225 \mathrm{~mL}$ of patient's blood and mixing them with $225 \mathrm{~mL}$ of Oxygen-Ozone gas (where Ozone concentration was $50 \mu \mathrm{g} / \mathrm{mL}$ gas).

Results and Discussion. Despite autohemotherapy was a high-potency curative treatment for groups I and II, it was palliative for group IV. For group III, it oscillated between being a curative or a palliative treatment with a statistically insignificant difference.

Conclusions. Autohemotherapy might be a recommended treatment for alveolar osteitis.

Keywords: alveolar; osteitis; major autohemotherapy.

\section{Introduction}

Alveolar osteitis (AO) is a very common complication of dental extraction [1]. Although Birn's suggestion [2] that $A O$ results from blood clot disintegration has gained wide acceptance, the exact etiology is still poorly understood $[3,4]$. Pain is the most important aspect of $\mathrm{AO}$ according to Fazakerlev and Field [5], and although a variety of treatment methods have been attempted to treat or alleviate this pain, considerable controversy exists regarding their relative efficacies $[3,6,7]$. Ozone is a very powerful healer and oxidant [8-13]. Since Wolff has introduced Ozone major Autohemotherapy (AHT) was a frequently used treatment method for a variety of conditions [14]. $\mathrm{AHT}$ enhances oxygen delivery to ischemic tissues, and in turn, improves general metabolism and activates the immune system as well; therefor it is a powerful healing treatment modality $[8-11,13]$. 
Literature, up to the best of my knowledge, is deprived of any studies for the effect of AHT (as a systemic form of Ozone application) in AO patients. The aim of the current study was to evaluate the efficacy of $\mathrm{AHT}$ as a treatment method for $\mathrm{AO}$ utilizing definitive parameters for diagnosis and outcome assessment taking in consideration that $A O$ treatment is pain relief-targeted rather than healing-targeted.

\section{Patients and methods}

The author examined patients in the Hosh Isa district (Al-Behera, Egypt) who presented with pain after dental extraction during the years 2004 through 2010. Patients diagnosed with AO ("dry socket") fulfilling inclusion criteria were divided into 4 groups according to pain severity (Table 1).

Table 1: Pain severity levels used to assign patients to groups

\section{Severity of Pain Description}

I Mild Patients had annoying or bothering pain during most awakening hours but did not need analgesics.

II Moderate Patients had pain that required and was relieved by analgesics (a maximum of three "bills" per day of the analgesic type that is usually taken by the patient).

III Severe Patients had pain that was not relieved by analgesics (a maximum of three "bills" per day of the analgesic type that is usually taken by the patient) but that did not interfere with normal daily activities (e.g., patients did not have to leave work and did not awaken during sleep).

IV Agonizing Patients had pain that was not relieved by analgesics (a maximum of three "bills" per day of the analgesic type that is usually taken by the patient) and that interfered with normal daily activities (e.g. the pain caused the patients to leave work or to awaken during the night).

All patients underwent brief saline irrigation of the socket with $2 \mathrm{~mL}$ normal saline $(0.9 \%$ solution $)$ to remove any debris. Major Autohemotherapy was carried out by withdrawing $225 \mathrm{~mL}$ of patient's blood by vacuum from an antecubital vein into a sterile glass bottle (Ozonosan, Iffezeim, Germany) containing $25 \mathrm{~mL}$ of $3.8 \%$ Sodium Citrate solution (Alamia gp, Cairo, Egypt) as an anticoagulant. Then the bottle was disconnected and the venous access was kept patent 
by a saline infusion. Blood was then continuously mixed with $225 \mathrm{~mL}$ of Oxygen-Ozone gas (where Ozone concentration was $50 \mu \mathrm{g} / \mathrm{mL}$ gas with a total dose of Ozone equivalent to $11.25 \mathrm{mg}$ ) produced by an Ozonline $80 \mathrm{E}$ generator (Medica srl, Bologna, Italy). Mixing was for at least 5 minutes with a concomitant gentle rotatory movement in order to avoid foaming. Then blood is reinfused over 15-20 minutes after disconnecting saline infusion. The whole system is Ozone-resistant $[13,15]$. AHT was performed every three days if pain was not eliminated.

This study complied with the Declaration of Helsinki, and the regional ethical review board of the research unit at Hosh Isa Medical Center approved the study.

\section{Inclusion criteria:}

1. Pain after simple dental extraction (forceps extraction)

2. Diagnosis of $A O$ (dry socket)

3. Age 25 to 55 years.

\section{Exclusion criteria:}

1. Signs or symptoms of an infected socket.

2. Systemic or local conditions hindering or otherwise affecting healing.

3. Disorders causing bleeding tendencies.

4. Tooth extraction during menstruation.

5. Pregnancy, lactation, or use of oral contraceptives.

6. Hormonal disturbances.

7. Smoking.

The effectiveness of the treatment modality in pain alleviation was evaluated according definitive criteria as shown in Table 2.

Table 2: Parameters for assessing treatment effectiveness

\section{Designation Criteria}

Curative Treatment was followed by disappearance of pain without other medication (or pain became too slight to be annoying or to lead the patient to seek medical or dental intervention).

Palliative

Treatment was followed by decreased pain severity but pain remained at least annoying, or treatment was followed by a decrease in the dose of analgesics taken, or both.

Ineffective

Treatment was not followed by noticeable diminution in pain severity (and pain remained at least annoying), or the treatment had a palliative effect that was not maintained to the end of a 5- minute visit. 
The total time needed for the patient not to seek medical or dental intervention was recorded for each group in order to assess effectiveness of the treatment applied. The potency of treatment modality was considered high if that period was 2 days or less, moderate if it was 3 or 4 days, and low if it was 5 days or more, as the total healing period typically ranges from 7 to 10 days [4]. If the curative effect was achieved within 1 day, thus requiring only a single application, the treatment was considered a definitive therapy.

\section{Results}

A total of 183 patients were included in the current study. The numbers of patients in groups I, II, III, and IV were 56, 78, 36, and 13, respectively. The effectiveness of AHT in each group is shown in Table 3, while tables 4 and 5 depict the potency. N.B.: the palliative, ineffective, palliative/ineffective (when the difference in-between was statistically insignificant) and curative/palliative (when the difference in-between was statistically insignificant) results could be collectively termed as noncurative.

AHT was a curative treatment method of a high potency in groups I and II. However, it was definitive therapeutic measure only for group I

Table 3: Number of patients allocated for each effect in each group and the decision according to the statistical analysis.

\begin{tabular}{|c|c|c|c|c|c|}
\hline & \multicolumn{3}{|c|}{$\begin{array}{c}\text { Numbers for each } \\
\text { AHT effect * }\end{array}$} & \multirow[t]{2}{*}{ Decision } & \multirow[t]{2}{*}{ Fisher's exact test } \\
\hline & C & $P$ & $\ln$ & & \\
\hline Group I & 55 & 1 & 0 & C & $\mathrm{P}<0.001$ (significant difference) \\
\hline Group II & 74 & 3 & 1 & C & $\mathrm{P}<0.001$ (significant difference) \\
\hline Group III & 21 & 15 & 0 & $\mathrm{C} / \mathrm{P}$ & $\mathrm{P}=0.41$ (insignificant difference) \\
\hline Group IV & 1 & 10 & 2 & $P$ & $\begin{array}{l}\mathrm{P}=0.003 \text { (significant difference } \\
\text { between curative and noncurative } \\
\text { results), } \mathrm{P}=0.039 \text { (significant } \\
\text { difference between } \mathrm{P} \text { and In results) }\end{array}$ \\
\hline
\end{tabular}

${ }^{*}$ AHT (Major Autohemotherapy) Effect: $C=$ curative, $P=$ palliative, In=ineffective, $C / P=$ curative or palliative with the difference being statistically insignificant

patients. Results of AHT in group III oscillated between being curative and palliative with a statistically insignificant difference. Furthermore, in group IV, AHT was palliative where it failed to demonstrate a more potent effect. 
Table 4: Potency of the curative effect.

\begin{tabular}{|c|c|c|c|c|c|c|c|c|}
\hline $\mathrm{Gr}$ * & 1 day & 2 days & 3 days & 4 days & 5 days & Median & Potency & $\begin{array}{c}\text { Test of } \\
\text { difference }\end{array}$ \\
\hline I & 42 & 10 & 3 & 0 & 0 & 1 & High & \multirow{2}{*}{$\begin{array}{c}\text { Extremely } \\
\text { significant } \\
(U=928.5, \\
z=5.27, \\
P<0.01)\end{array}$} \\
\hline II & 20 & 29 & 11 & 10 & 4 & 2 & High & \\
\hline \multicolumn{9}{|c|}{${ }^{*} \mathrm{Gr}=$ group, $₫$ Mann Whitney $U$ test } \\
\hline
\end{tabular}

Table 5: Determination if AHT was a definitive therapy or not.

\begin{tabular}{|c|c|c|c|c|}
\hline Group & 1 day (once) & $>1$ day & P value* & Decision \\
\hline I & 42 & 13 & $<0.001$ & definitive \\
\hline$I$ & 20 & 54 & $<0.001$ & not definitive \\
\hline \multicolumn{4}{|c|}{ * $P$ value for Fisher's exact test } \\
\hline \multicolumn{4}{c}{}
\end{tabular}

\section{Discussion}

In order to study as homogenous group of patients as possible, the study population was restricted to otherwise healthy patients who underwent simple (forceps) extraction and did not have any known conditions affecting their healing capacities, since $\mathrm{AO}$ seems to reflect an interference with the healing process, resulting in blood clot loss [2]. The inclusion and exclusion criteria were determined accordingly.

To my knowledge, no published studies of $\mathrm{AO}$ treatment have classified patients according to pain severity or analyzed the outcome according to definitive assessment criteria. However, in the current study, patients were categorized into 4 major groups according to pain severity. The severity rating was not based on the patient's description (for example, use of words like "mild" or "severe") or on the patient's estimation on a visual pain analogue scale; rather, it relied on behavioral measures: the need for analgesics and whether the condition interfered with daily life. On assessing the outcome of treatment methods in the current study, only 3 possibilities, all welldefined, were considered. These features, in addition to the size of the population, appear unique to the current study.

In the current research, AHT demonstrated a graded therapeutic effect through groups I to IV. Its highest level of potency was shown in group I where it acted as a definitive high-potency curative treatment method. However, in group II, it tended to be less effective, and 
furthermore, it was least effective in higher severity groups (groups III and IV) to end to be only palliative in group IV. Despite of that spectrum, AHT might be considered an accepted modality reflecting the healing capability of systemic Ozone in AO patients.

Results of the current study might follow the same stream of other studies indicated that AHT is a powerful healer [8-11,13]. However, AHT was not intended or assessed as a healer, but rather, treating pain was the target. AHT increases oxygen delivery to ischemic tissues improving general metabolism and activating the immune system [8-11, 13]. Compressive stresses delivered to alveolar socket walls due to extraction forces might lead to a state of ischemia. Lactic acid produced by anaerobic glycolysis that prevails during ischemia in addition to other noxious substances might be causes for blood clot disintegration and for nerve irritation and therefore pain. Reversing that ischemia and washing out the noxious substances by reperfusion in addition to ceasing anaerobic glycolysis by the high oxidative power of Ozone could be a probable mechanism for the therapeutic effect of AHT.

\section{Conclusions}

Alveolar osteitis results from blood clot disintegration. Until now, there has been no generally agreed on treatment of choice. In the current prospective study, AHT was assessed as a potential treatment. AHT showed a graded therapeutic effect as it was definitive high-potency curative treatment method for group I and was only palliative for group IV patients. It might cause reversal of the ischemic condition that could develop as a result of compressive stresses during dental extraction. AHT could be recommended as one treatment modality for $\mathrm{AO}$ for mild and moderate pain patients.

The author declares no conflict of interest.

\section{Acknowledgment}

I am deeply grateful to Dr. Barbara Gastel, Texas A\&M University, for help in refining this paper.

\section{References}

1. Kolokythas A, Olech E, Miloro M. Alveolar Osteitis: A Comprehensive Review of Concepts and Controversies. Int J Dent [Internet]. 2010:1-10. Available from: http://www.pubmedcentral.nih.gov/articlerender.fcgi? artid=2905714\&tool=pmcentrez\&rendertype=abstract

2. Birn H. Etiology and pathogenesis of fibrinolytic alveolitis ("dry socket"). Int J Oral Surg [Internet]. 1973;2:215-63. Available from: https:// www.sciencedirect.com/science/article/pii/S0300978573800456

3. Faizel S, Thomas S, Yuvaraj V, Prabhu S, Tripathi G. Comparision Between Neocone, Alvogyl and Zinc Oxide Eugenol Packing for the Treatment of Dry Socket: A Double Blind Randomised Control Trial. J Maxillofac Oral Surg [Internet]. 2014;14(2):312-20. Available from: http:// 
www.ncbi.nlm.nih.gov/pubmed/26028852

4. Gowda GG, Viswanath D, Kumar M, Umashanker D. Dry Socket (Alveolar Osteitis): Incidence, Pathogenesis, Prevention and Management. J Indian Acad Oral Med Radiol [Internet]. 2013;25(3):196-9. Available from: http:// www. jaypeejournals. com/eJournals/Show Text.aspx? $I D=6534 \&$ Type $=F R E E \& T Y P=T O P \& I N=\_$eJournals $/ \mathrm{images} /$ JPLOGO.gif\&IID=493\&isPDF=YES

5. Fazakerlev M, Field E. Dry socket: a painful postextraction complication (a review). Dent Updat [Internet]. 1991;18:31-5. Available from: https:// www.ncbi.nlm.nih.gov/pubmed/1936428

6. Alexander R. Dental extraction wound management: a case against medicating postextraction sockets. J Oral Maxillofac Surg [Internet]. 2000;58(5):538-51. Available from: https://www.ncbi.nlm.nih.gov/pubmed/ 10800910

7. Blum IR. Contemporary views on dry socket (alveolar osteitis): a clinical appraisal of standardization, aetiopathogenesis and management: a critical review. Int J Oral Maxillofac Surg [Internet]. 2002;31:309-17. Available from: http://dx.doi.org/10.1054/ijom.2002.0263

8. Bocci V, Zanardi I, Travagli V. Ozone: A New Therapeutic Agent in Vascular Diseases. Am J Cardiovasc Drugs [Internet]. 2011 Apr [cited 2017 Dec 22];11(2):73-82. Available from: http://link.springer.com/ 10.2165/11539890-000000000-00000

9. Bocci V, Borrelli E, Travagli, V, Zanardi I. The ozone paradox: Ozone is a strong oxidant as well as a medical drug. Med Res Rev [Internet]. 2009 Jul 1 [cited 2017 Dec 22];29(4):646-82. Available from: http://doi.wiley.com/ 10.1002/med.20150

10. Bocci V. Ozone as Janus: this controversial gas can be either toxic or medically useful. Mediators Inflamm [Internet]. 2004 [cited 2017 Dec 18]; 13(1):3-11. Available from: http://www.ncbi.nlm.nih.gov/pubmed/15203558

11. Abreu J M, Fontén N G, García A B, Rodríguez S N, Llanes E L CSM. Efficacy of OLEOZON $®$ compared to Alvogil in the treatment of alveolitis. J Ozone Ther [Internet]. 2015;1(1):1-8. Available from: https:// www.journalofozonetherapy.org/700-2/

12. Bocci V. Ozone A new medical drug. 2nd ed. Dordrecht, The Netherlands: Springer Publ; 2011.

13. Wolff $\mathrm{H}$. Die Behandlung peripherer Durchbutungsstorungen mit Ozon. Erfahr Hk. 1974;23:181-4.

14. Bocci V. Oxygen-ozone therapy. A critical evaluation. Dordrecht, The Netherlands: Kluwer Academic Publishers; 2002. 1-427 p. 